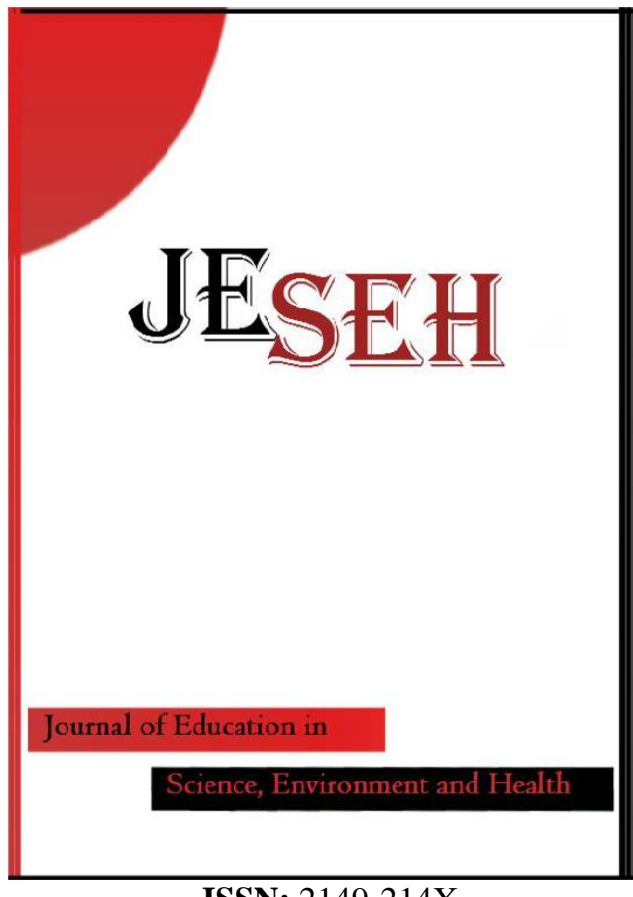

Journal of Education in Science, Environment and Health

www.jeseh.net

Science Amotivation Scale: Validity and Reliability Study

Busra Karaca ${ }^{1}$, Solmaz Aydin ${ }^{2}$

${ }^{1}$ Ministry of National Education

${ }^{2}$ Kafkas University

ISSN: $2149-214 \mathrm{X}$

To cite this article:

Karaca, B. \& Aydin, S. (2020). Science amotivation scale: Validity and reliability study. Journal of Education in Science, Environment and Health (JESEH), 6(4), 297-308. DOI:10.21891/jeseh.769444

This article may be used for research, teaching, and private study purposes.

Any substantial or systematic reproduction, redistribution, reselling, loan, sub-licensing, systematic supply, or distribution in any form to anyone is expressly forbidden.

Authors alone are responsible for the contents of their articles. The journal owns the copyright of the articles.

The publisher shall not be liable for any loss, actions, claims, proceedings, demand, or costs or damages whatsoever or howsoever caused arising directly or indirectly in connection with or arising out of the use of the research material. 


\title{
Science Amotivation Scale: Validity and Reliability Study
}

\author{
Busra Karaca, Solmaz Aydin
}

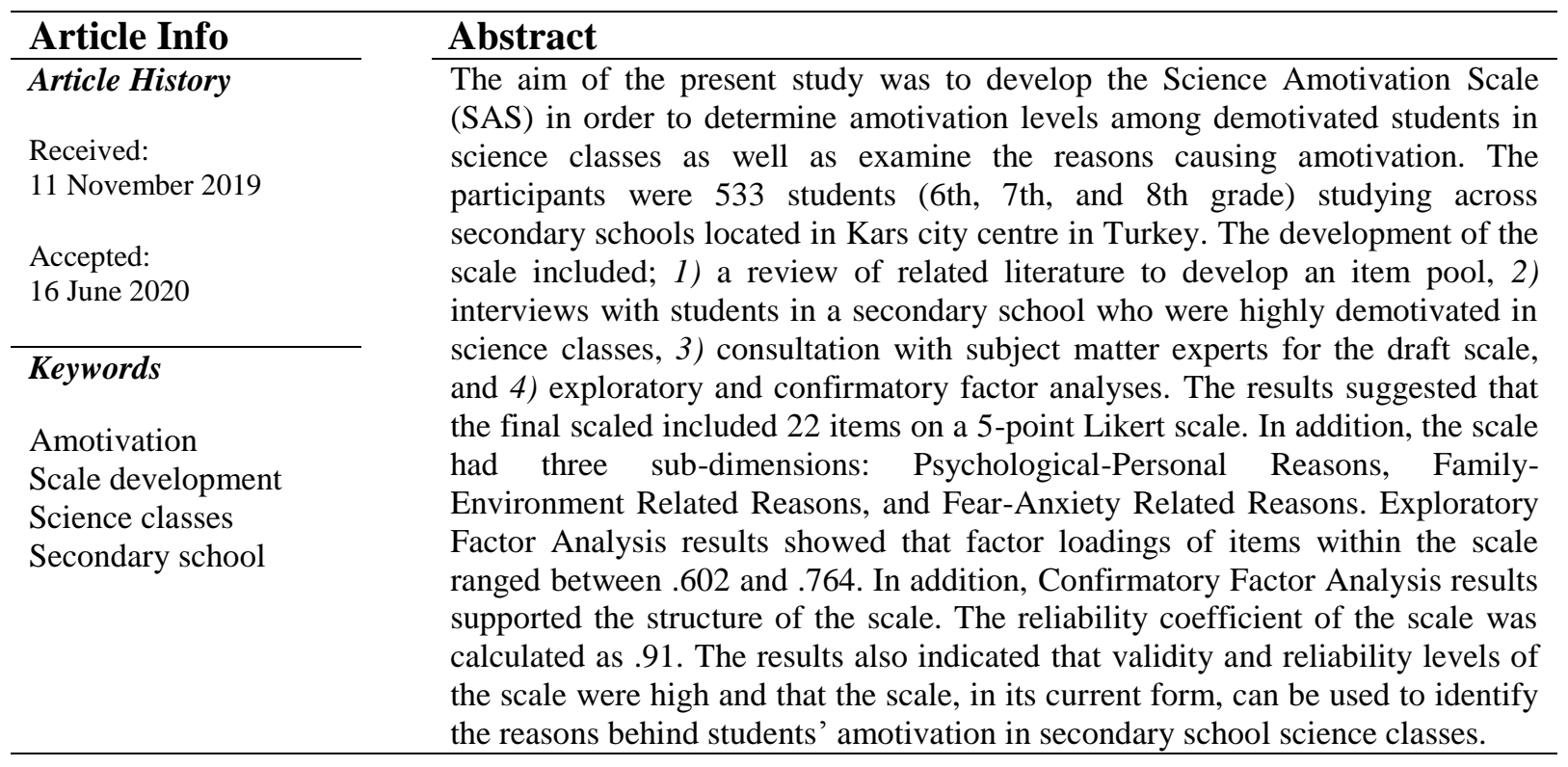

\section{Introduction}

Science courses have an abstract and equally complex structure. Therefore, students may experience difficulties in science subjects from time to time. Motivating students becomes an important point of consideration in order to be able to overcome the difficulties that can be faced during science education. Research has shown that motivation affects students' academic success in the classroom (Alvord \& Glass, 1974; Bart, 1978, Pintrich \& De Groot, 1990; Trumper, 1995). Atay (2014) has found that individuals' purposeful participation in the learning process positively affects learning and students become more successful in learning scientific knowledge. Being motivated will positively affect an individual's learning and allow the learning process to be more effective. In this sense, identifying factor that can affect students' motivation becomes an important point of consideration to increase their motivation. Undoubtedly, the learning outcomes for a motivated student would be different from the learning outcomes for a demotivated student.

Amotivation results from not caring about an activity, feeling the self to be incompetent, or not believing that the self will be able to reach the desired outcome (Deci \& Ryan, 2000). An individual's imperceptions or disbelief in his/her skills and efforts are one of the main sources of amotivation (Legault, Green-Demers, \& Pelletier, 2006). Amotivation, which is a big problem not only for teachers but also for students, is one of the most frequently experienced sources of failure (Green-Demers, Legault, Pelletier \& Pelletier, 2008). More specifically, high levels of student amotivation, in most cases, can put the teacher in a tight spot and cause them to make wrong decisions (Dicke, Lüdtke, Trautwein, Nagy \& Nagy, 2012).

Research studies revealed that individuals with high levels of motivation are able to achieve better results compared to those who are less motivated (Green, Nelson, Martin ve Marsh, 2006; Linnenbrink ve Pintrich, 2002; Pintrich ve Schunk, 1996). Motivation is a prequisite for classroom success and school satisfaction (Vallerand et al., 1991). According to self-determination theory, amotivation is the most worrisome state of academic motivation. While motivated students' actions are supported by feelings such as competition and effort, amotivated students have the tendency to not participate in activities, not taking any taks, not comleting a given task, and absenteeism (Vallerand et al., 1991). Demotivated students can experience negative feelings such as anxiety, fear, disappointment, anger, hopelessness, and unhappiness. Therefore, an individual's amotivation can increase incrementally and result in unproductivity at classroom as well as societal levels. In this sense, student amotivation becomes a significant problem that needs to be solved not only in the context of an individual students' academic success but also in the context of the whole class as well as the school 
(Legault, Green-Demers \& Pelletier, 2006). Therefore, it is considered that the reasons which negatively affect student motivation should be determined. More specifically, if teachers become aware of the factors that cause their students to become amotivated in the classroom then they can shape teaching and learning processes and their behaviour in a way that contributes towards the solution of those problems.

Table 1. Factors that were found to be related to student amotivation

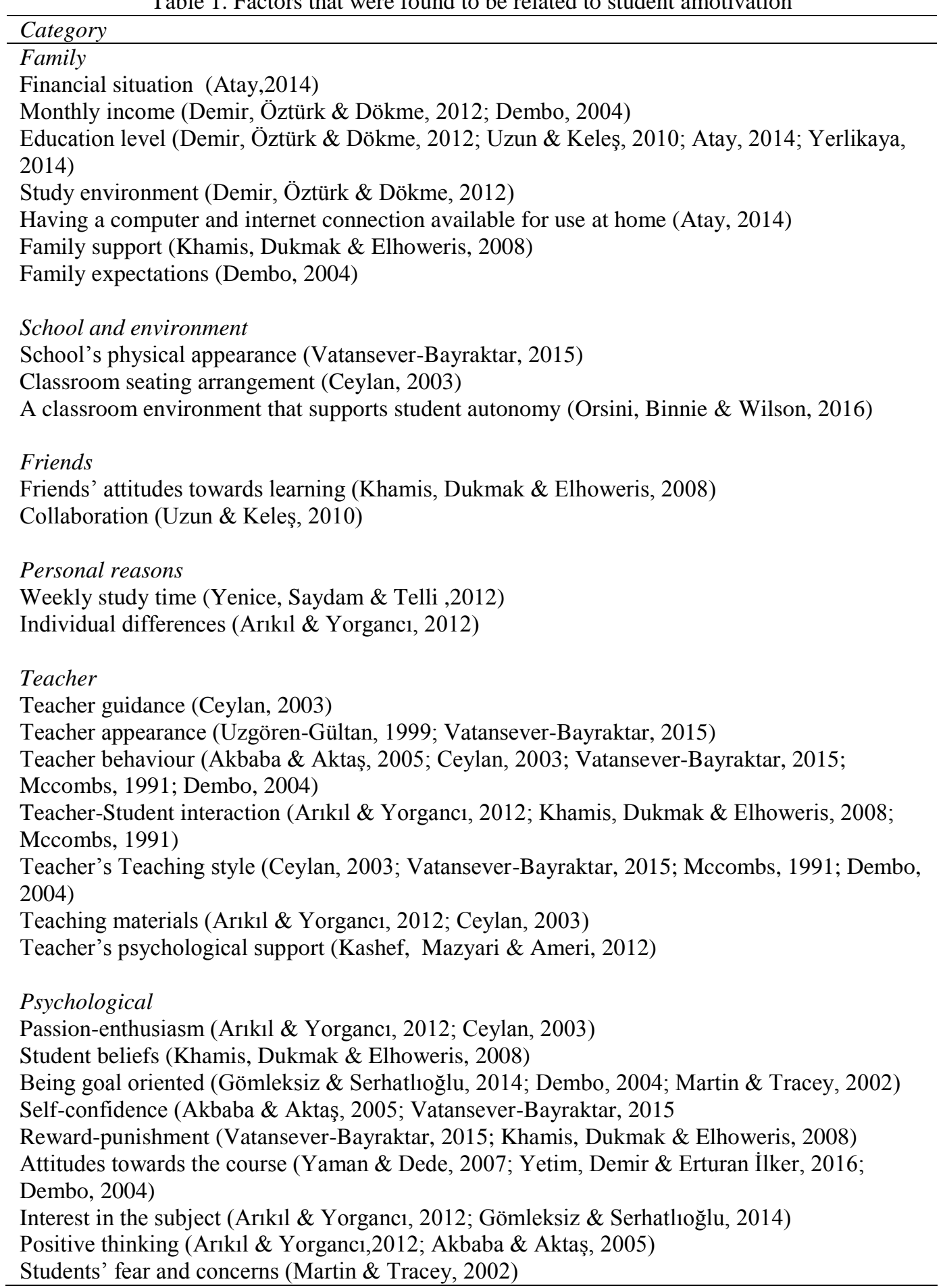

The review of literature on this subject suggests that most studies have been conducted to measure students' motivation levels and scales have been developed to realize this aim (Aydın, Yerdelen, Gürbüzoğlu-Yalmancı \& Göksu, 2014; Azizoğlu \& Çetin 2009; Dede \& Yaman, 2007; Uzun \& Keleş, 2010; Yenice, Saydam \& Telli, 2012).. It has been found that various international studies have been conducted on amotivation (i.e. Legault, Green-Demers \& Pelletier, 2006; Pelletier, Dion, Tuson \& Green-Demers, 1999; Vlachopoulos \& Gigoudi, 2008). Nevertheless, there has not been enough research on this subject in the context of Turkey. The only study 
that has been conducted in the context of Turkey is Illter's (2019) study which aimed to adapt the "Academic Amotivation Scale" developed by Legault, Green-Demers and Pelletier (2006) into the Turkish culture. No amotivation scale was found that was specifically oriented towards science classes. The aim of the present study is to contribute to the literature by developing a valid and reliable scale which can be used to measure students' amotivation levels and understand the reasons for their amotivation.

\section{Method}

The aim of the present study is to develop the Science Amotivation Scale (SAS). Survey research design, a quantitative research approach, was followed to achieve this aim and collect data. The development of the scale included; 1) a review of related literature to develop an item pool, 2) interviews with students in a secondary school who were highly demotivated in science classes, 3) consultation with subject matter experts for the draft scale, and 4) exploratory and confirmatory factor analyses. The universe of the study consisted of 6th, 7th, and 8th grade students studying in secondary schools in Kars city centre in Turkey. A different group of participants (sample) was selected for each phase of the study and analyses were conducted using the collected data. The size of each sample is specified under related sub-headings.

Table 2. Student responses received following the interviews

\begin{tabular}{lc}
\hline Reasons affecting amotivation & $\begin{array}{c}\text { Number of students mentioning a } \\
\text { reason (5 students) }\end{array}$ \\
\hline Study environment & 3 \\
Use of internet & 4 \\
Family support & 5 \\
Family expectations & 1 \\
School's physical appearance & 3 \\
Classroom seating arrangement & 3 \\
An environment supporting student autonomy & 2 \\
Friends' attitudes towards learning & 3 \\
Collaboration & 3 \\
Teacher guidance & 1 \\
Teacher behaviours & 5 \\
Student-Teacher interaction & 2 \\
Teacher's teaching style & 3 \\
Teacher's teaching materials & 3 \\
Teacher's psychological support & 3 \\
Being passionate and enthusiastic & 3 \\
Student beliefs & 3 \\
Students being goal-oriented & 3 \\
Student self-confidence & 3 \\
Reward and punishment & 3 \\
Attitudes towards the course & 3 \\
Interest in the subject & 3 \\
Positive thinking & 3 \\
Students' fears and concerns & 3 \\
Weekly study time & 3 \\
Individual differences & 3 \\
\hline & 3 \\
\hline
\end{tabular}

\section{Creation of item pool}

In the initial phase, a review of related literature was conducted in order to create the item pool. This review focused on identifying the factors that cause amotivation among students. Those factors are summarized in Table 1. Those factors were transformed into items and included in the item pool. Furthermore, interviews were arranged to be held with demotivated students in order to write further items. Therefore, the Academic Motivation Scale for Learning Science (AMSLS) was administered to $6^{\text {th }}, 7^{\text {th }}$, and $8^{\text {th }}$ grade students in a 
secondary school that was not part of the study sample for the main study. The reason for administering this scale was to identify students who were demotivated in science classes.

AMSLS is a scale developed by Aydın, Yerdelen, Gürbüzoğlu-Yalmancı and Göksu (2014) and adapted for science classes by Çekim (2016). It is used to measure students' academic motivation in science classes and consists of 19 items and four sub-dimensions. Those sub-dimensions are; intrinsic motivation, extrinsic motivation-career, extrinsic motivation-social, and amotivation. Due to the focus of the present study, only the results of the amotivation sub-dimension were taken into consideration. Five students among those who scored highest in this sub-dimension (indicating highest levels of amotivation) were invited to semi-structured interviews. Students were asked questions linked to the factors identified in the review of literature for amotivation. Those questions were:

$>$ Do you think your family affects your motivation in science classes?

$>$ Do you think that your school's physical appearance affects your motivation in science classes?

$>$ Do you think your friends affect your motivation in science classes?

$>$ Do you think your teacher affects your motivation in science classes?

$>$ Do you think that your psychological mood affects your motivation in science classes?

$>$ Are there any other reasons that you think affect your motivation in science classes?

The content analysis of the responses received from students, the reasons mentioned to affect amotivation are summarized in Table 2. The item pool developed following the above steps were examined by three subject matter experts and the item pool was finalized following the revisions suggested by the experts. The scale consisted of 42 items to be administered on a 5-point Likert scale where "1" represented "Strongly disagree" and " 5 " represented "Strongly agree".

\section{Results and Discussion}

\section{Exploratory Factor Analysis}

Initially the scale was administered to 261 secondary school students $\left(6^{\text {th }}, 7^{\text {th }}\right.$, and $8^{\text {th }}$ grade) using simple random sampling procedures and the 42-item scale was factor analysed. Exploratory Factor Analysis (EFA) results indicated that 22 items had a loading value of .518 and over. Next, the factor analysis was run again with those 22 items and the KMO value was calculated as .93. This suggested that the dataset was fit for factor analysis. Moreover, the Bartlett Sphericity test indicated that there was a considerably large relationship among variables to conduct the factor analysis $(\chi 2=3027, \mathrm{p}<, 001)$. The EFA results indicated that there were 3 factors with an eigenvalue higher than 1. Similarly, the analysis of the scree plot suggested that there were three areas above the curve point (Figure 1).

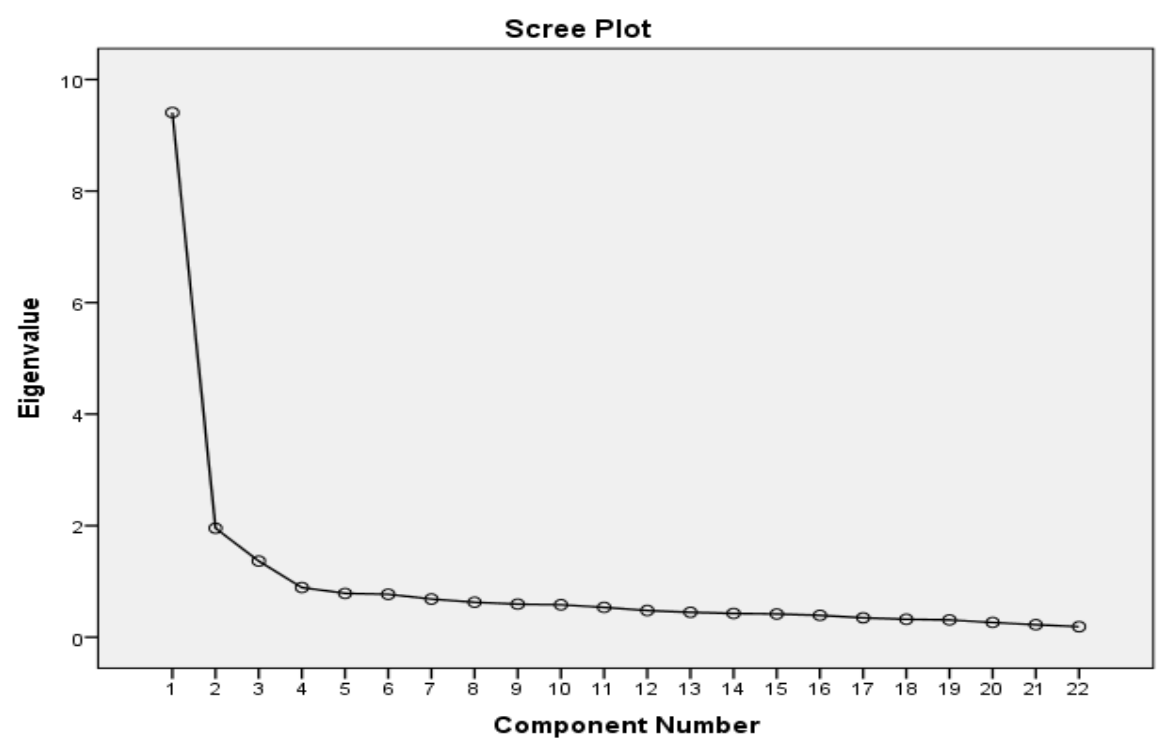

Figure 1. Eigenvalues' distribution graph

Following these results, the dataset was rotated using the Varimax method and it was decided that the scale had a 3-factor structure. The factors were named based on the items that loaded onto them; Psychological-Personal 
(PP), Family-Environment (FE), and Fear-Anxiety (FA). The total variance that those three factors explained was $57.85 \%$ (see Table 3 ).

Table 3. Total variance explained by the factors

\begin{tabular}{llll}
\hline Factors & Eigenvalue & Explained variance $(\%)$ & Total variance $(\%)$ \\
\hline PP & 9,408 & 32,572 & 32,572 \\
FE & 1,954 & 13,417 & 45,988 \\
FA & 1,366 & 11,864 & 57,852 \\
\hline
\end{tabular}

Each item's factor loadings are summarized in Table 4. According to the Varimax rotation technique in Table 4, the first factor (Family-Environment) consists of items 1, 2, 3, 9 and 26; the second factor (Fear-Anxiety) consist of items 21, 32 and 36; and items 22, 24, 33, 35, 37, 38, 39, 40, 41, 7, 13, 16, 18 and 19 constitute the third factor (Psychological-Personal).

Table 4. SAS factor loadings based on the 3-factor solution using varimax method

\begin{tabular}{|c|c|c|c|}
\hline \multirow[t]{2}{*}{ Items } & \multicolumn{3}{|c|}{ Factors } \\
\hline & $\mathrm{FE}$ & FA & PP \\
\hline $\begin{array}{l}\text { 1. Because my family's financial situation } \\
\text { prevents me from buying materials necessary for } \\
\text { science classes }\end{array}$ & .790 & & \\
\hline $\begin{array}{l}\text { 2. Because I do not have Internet at home to do } \\
\text { my science homework }\end{array}$ & .775 & & \\
\hline $\begin{array}{l}\text { 3. Because my parent's education level is not } \\
\text { high enough to support me in science classes. }\end{array}$ & .764 & & \\
\hline $\begin{array}{l}\text { 9. Because I do not have an opportunity to study } \\
\text { for science classes with my friends. }\end{array}$ & .719 & & \\
\hline $\begin{array}{l}\text { 26. Because I do not have a computer to do my } \\
\text { science homework. }\end{array}$ & .603 & & \\
\hline $\begin{array}{l}21 \text {. Because I fear that I will not be successful in } \\
\text { science classes. }\end{array}$ & & .658 & \\
\hline $\begin{array}{l}\text { 32. Because I abstain from asking questions to } \\
\text { my teacher when I do not understand the subject } \\
\text { in science classes. }\end{array}$ & & .518 & \\
\hline $\begin{array}{l}\text { 36. Because the subjects in science classes are } \\
\text { difficult for me. }\end{array}$ & & .638 & \\
\hline 22. Because I do not like science classes. & & & .652 \\
\hline 24. Because I do not have a goal to learn science. & & & 648 \\
\hline 33. Because I do not like my science teacher. & & & .798 \\
\hline $\begin{array}{l}\text { 35. Because my teacher does not believe that I } \\
\text { can be successful in science. }\end{array}$ & & & .716 \\
\hline $\begin{array}{l}\text { 37. Because I do not know why I should learn } \\
\text { science. }\end{array}$ & & & 627 \\
\hline $\begin{array}{l}\text { 38. Because I do not learn new information in } \\
\text { science classes. }\end{array}$ & & & 602 \\
\hline $\begin{array}{l}\text { 39. Because science classes are not important for } \\
\text { me. }\end{array}$ & & & .763 \\
\hline $\begin{array}{l}\text { 40. Because my family does not believe that I can } \\
\text { be successful in science. }\end{array}$ & & & .722 \\
\hline 41. Because learning science will not be useful. & & & 671 \\
\hline 7. Because I do not like my school. & & & .754 \\
\hline $\begin{array}{l}\text { 13. Because our teacher does not interact with us } \\
\text { when teaching science lessons. }\end{array}$ & & & .711 \\
\hline $\begin{array}{l}\text { 16. Because I do not think science classes are } \\
\text { necessary. }\end{array}$ & & & .708 \\
\hline 18. Because I do not want to learn science. & & & 686 \\
\hline $\begin{array}{l}\text { 19. Because I do not believe that I can be } \\
\text { successful in science. }\end{array}$ & & & 684 \\
\hline
\end{tabular}

Note: FE: Family-Environment, FA: Fear-Anxiety, PP: Psychological-Personal 


\section{Confirmatory Factor Analysis (3 Factors)}

Confirmatory Factor Analysis (CFA) was conducted to establish the construct validity of the Science Amotivation Scale (SAS). The 22-item version of SAS was administered to a new cohort of participants. 272 students $\left(6^{\text {th }}, 7^{\text {th }}\right.$, and $8^{\text {th }}$ grade) from three secondary schools were selected using simple random sampling strategy. Model indices that were achieved following CFA and using the Maximum Likelihood method indicated that the model has a good fit $\left(\mathrm{x}^{2}=531,27 ; \mathrm{p}<, 05 ; \mathrm{x}^{2} / \mathrm{sd}=2,617\right.$; RMSEA $=, 077$; NFI $=, 93 ; \mathrm{CFI}=, 96$; $\mathrm{IFI}=$,96; NNFI= 95). Factor correlations, mean, standard deviation, and reliability coefficients were calculated for the 22-item final version of the scale and the results supported SAS's construct validity. Parameter $(\lambda)$ estimates for the 22 items are presented in Table 5 .

Table 5. Parameter values $(\lambda)$

\begin{tabular}{|c|c|c|c|}
\hline \multirow[t]{2}{*}{ Items } & \multicolumn{3}{|c|}{ Factors } \\
\hline & $\mathrm{FE}(\lambda)$ & FA $(\lambda)$ & $\mathrm{PP}(\lambda)$ \\
\hline $\begin{array}{l}1 \text { Because my family's financial situation prevents me from buying } \\
\text { materials necessary for science classes }\end{array}$ & .58 & & \\
\hline 2 Because I do not have Internet at home to do my science homework & .69 & & \\
\hline $\begin{array}{l}3 \text { Because my parent's education level is not high enough to support me in } \\
\text { science classes. }\end{array}$ & .55 & & \\
\hline $\begin{array}{l}5 \text { Because I do not have an opportunity to study for science classes with my } \\
\text { friends. }\end{array}$ & .61 & & \\
\hline 13 Because I do not have a computer to do my science homework. & .65 & & \\
\hline 10 Because I fear that I will not be successful in science classes. & & 69 & \\
\hline $\begin{array}{l}14 \text { Because I abstain from asking questions to my teacher when I do not } \\
\text { understand the subject in science classes. }\end{array}$ & & .72 & \\
\hline 17 Because the subjects in science classes are difficult for me. & & .68 & \\
\hline 11 Because I do not like science classes. & & & ,66 \\
\hline 12 Because I do not have a goal to learn science. & & & .56 \\
\hline 15 Because I do not like my science teacher. & & & .59 \\
\hline 16 Because my teacher does not believe that I can be successful in science. & & & .73 \\
\hline 18 Because I do not know why I should learn science. & & & .72 \\
\hline 19 Because I do not learn new information in science classes. & & & .71 \\
\hline 20 Because science classes are not important for me. & & & .77 \\
\hline 21 Because my family does not believe that I can be successful in science. & & & .65 \\
\hline 22 Because learning science will not be useful. & & & .71 \\
\hline 4 Because I do not like my school. & & & .49 \\
\hline $\begin{array}{l}6 \text { Because our teacher does not interact with us when teaching science } \\
\text { lessons. }\end{array}$ & & & .53 \\
\hline 7 Because I do not think science classes are necessary. & & & .68 \\
\hline 8 Because I do not want to learn science. & & & .72 \\
\hline 9 Because I do not believe that I can be successful in science. & & & .51 \\
\hline
\end{tabular}

Factor correlations of the scale ranged between .55 and .76. All factor correlations were significant at $p<.01$ level. There were medium-level, positive relationships among factors (Table 6). Mean, standard deviation, and reliability coefficients for each factor are presented in Table 7.

Table 6. Factor correlations coefficient

\begin{tabular}{llll}
\hline Factors & FE & FA & PP \\
\hline FE & 1 & $.76^{*}$ & $.60^{*}$ \\
FA & & 1 & $.55^{*}$ \\
PP & & & 1 \\
\hline
\end{tabular}

Table 7. Mean and standard deviation for SAS's sub-dimensions

\begin{tabular}{llcc}
\hline Factors & $\mathrm{N}$ & Mean & $\mathrm{Sd}$ \\
\hline FE & 272 & 1.81 & .91 \\
FA & 272 & 2.19 & 1.09 \\
PP & 272 & 1.61 & 0.75 \\
\hline
\end{tabular}


In addition the results of the reliability analysis show that the reliability coefficient of the Family-Environment sub-dimension was .76 , reliability coefficient for the Fear-Anxiety sub-dimension was .66, and reliability coefficient for the Psychological-Personal sub-dimension was .90. Moreover, Cronbach's alpha value for the whole scale was calculated as .91 .

\section{Confirmatory Factor Analysis (Single Factor)}

Another round of CFA for one factor structure was conducted using the data collected from 406 secondary schools in order to decide whether SAS can be used to measure students' amotivation levels in science classes. The fit indices achieved suggested that the scale can also be used in its single factor structure $\left(\mathrm{x}^{2}=698,98 ; \mathrm{p}<, 05\right.$; $\mathrm{x}^{2} / \mathrm{sd}=3,530 ; \mathrm{RMSEA}=, 079 ; \mathrm{SRMR}=, 040 ; \mathrm{NFI}=, 98 ; \mathrm{CFI}=, 99 ; \mathrm{IFI}=$,99; RFI= ,98; GFI= ,86; NNFI= ,99). Those results supported the idea that SAS can measure the factors which it is intended to measure and can be used to identify students' amotivation levels as well as the reasons of amotivation.

\section{Conclusion}

The present study aimed to develop the Science Amotivation Scale (SAS) which can be used to measure students' levels of amotivation and reasons behind their amotivation in science classes. Initially, a review of literature was conducted to create an item pool and interviews were held with students who had high levels of amotivation in science classes. The item pool included a number of dimensions such as family, friends, teacher, personal and psychological reasons, school, and environment. The initial item pool included 42 items which decreased to 22 items with a 3 -factor structure following Exploratory Factor Analysis (EFA). After analysing the items that loaded onto each factor, the three factors were named as; Family-Environment (FE), Fear-Anxiety (FA), and Psychological-Personal (PP).

Within the Family-Environment factor, it is understood that various factors such as families' financial situation, monthly income, parents' level of education, availability of the Internet at home, having a computer for use, family support, family expectations, and opportunities for students to collaborate with their friends affect students' motivation (Atay, 2014; Demir, Öztürk \& Dökme, 2012; Uzun \& Keleş, 2010; Yerlikaya, 2014; Khamis, Dukmak \& Elhoweris, 2008; Dembo, 2004). Deci and Ryan (1985) noted that social factors such as teachers, family, and friends affect motivation. Similarly, Legault, Green-Demers and Pelletier (2006) underlined that teachers, family, and friends are important social support factors which have effects on students' amotivation.

In addition, investigation of factors related to fear and anxiety which cause amotivation among students indicates that not believing that they could succeed in science classes, abstaining from asking questions to the teacher, and finding the topic to be difficult cause fear and anxiety. Martin and Tracey (2002) highlighted that fear and anxiety affected students' motivation. In their research, Green-Demers, Legault, Pelletier and Pelletier (2008) studied amotivation under four sub-dimensions. Those sub-dimensions are; (a) deficient ability beliefs, (b) deficient effort beliefs, (c) insufficient academic values, and (d) unappealing characteristics of school tasks. Thus, students' fears and anxiety might result from their lack of confidence in their abilities and unappealing school tasks.

The analysis of studies conducted on factors affecting students' motivation suggested that psychological and personal reasons affect students' motivation. These factors included various sub-dimensions such as students being passionate and enthusiastic, their beliefs, their goal orientations, self-confidence, reward and punishment, attitudes towards the course, being interested in the subject, positive thinking, weekly study time and individual differences (Arık1l \& Yorganc1, 2012; Ceylan, 2003; Khamis, Dukmak \& Elhoweris, 2008; Gömleksiz \& Serhatlığlu, 2014; Dembo, 2004;; Akbaba \& Aktaş, 2005; Vatansever-Bayraktar, 2015; Yaman \& Dede, 2007; Yenice, Saydam \& Telli, 2012; Yetim, Demir \& İlker, 2016). Zimmerman, Bandura and Martinez-Pons (1992) stated that motivation depends on self-regulation and personal goals. Raffini (1993), on the other hand, underlined that students do not perceive school as an important activity if their basic psychological and academic needs are not met in the school environment. Therefore, it is important for student motivation that teachers create an educational environment in which students feel psychologically safe.

Lastly, the scale's three-factor structure was confirmed using Confirmatory Factor Analysis (CFA) and the scale's construct validity was established. Furthermore, an extra layer of analysis (one-factor CFA) was conducted to test whether the scale can be used as a whole to measure students' amotivation levels and CFA 
results indicated that the scale can be used for this purpose. Cronbach Alpha reliability coefficients were calculated as .76 for the Family-Environment factor, .90 for the Psychological-Personal factor, .66 for the FearAnxiety factor, .91 for the whole scale. These analyses suggested that the Science Amotivation Scale (SAS) is a valid and reliable scale that can be used to measure secondary school science students' amotivation levels and the reasons behind their amotivation.

\section{Scientific Ethics Declaration}

The author(s) declare that the scientific ethical and legal responsibility of this article published in JESEH journal belongs to the author(s).

\section{Acknowledgements or Notes}

This article was prepared by benefiting from Karaca's (2019) master thesis.

\section{References}

Akbaba, S. \& Aktaş, A. (2005). İçsel motivasyonun bazı değişkenler açısından incelenmesi [Searching internal motivation according to some variables]. Marmara Üniversitesi Atatürk Eğitim Fakültesi Eğitim Bilimleri Dergisi, 21(21), 19-42.

Alvord, D. J. \& Glass, L. W. (1974). Relationships between academic achievement and self-concept. Science Education, 58(2), 175-179.

Arıkıl, G. \& Yorganc1, B. (2012). Öğretmenlerin, öğretmen adaylarının ve ögrencilerin motivasyonu algllama farklılıkları. X. Ulusal Fen Bilimleri ve Matematik Eğitimi Kongresi. Niğde Üniversitesi Eğitim Fakültesi.

Atay, A. D. (2014). Ortaokul ögrrencilerinin fen öğrenmeye yönelik motivasyon düzeylerinin ve üstbilişsel farkındalıklarının incelenmesi. (Master thesis). Adnan Menderes University, Fen Bilimleri Enstitüsü, Aydın.

Aydın, S., Yerdelen S., Gürbüzoğlu-Yalmancı S. \& Göksu, V. (2014). Academic motivation scale for learning biology: A scale development study. Education and Science, 39(176),425-435.

Azizoğlu, N. \& Çetin, G. (2009). 6 ve 7. Sınıf öğrencilerinin öğrenme stilleri, fen dersine yönelik tutumları ve motivasyonları arasındaki ilişki [Six And Seventh Grade Students' Learning Styles, Attitudes Towards Science And Motivations]. Kastamonu Ĕ̈itim Dergisi, 17(1), 171-182.

Bart, W. M. (1978). Formal operations among high school adolescents from lower and middle socio-economic classes: An investigation of the scholastic import, psychometric structures, and styles of formal reasoning. Unpublished final report to the Spencer Foundation, Chicago.

Ceylan, M. (2003). İki öğretmenin sınıf içinde motivasyon değişkenlerini dikkate alma davranışlarının betimlenmesi. (Master thesis). Anadolu Üniversitesi, Eğitim Bilimleri Enstitüsü, Eskişehir.

Deci, E. L. \& Ryan, R. M. (1985). Intrinsic motivation and self determination in human in behavior. New York: Plenum Press.

Deci, E. L. \& Ryan, R. M. (2000). The "what" and "why" of goal pursuits: Human needs and the selfdetermination of behavior. Psychological Inquiry, 11(4), 227-268.

Dede, Y. \& Yaman, S. (2008). Fen öğrenmeye yönelik motivasyon ölçeği: Geçerlik ve güvenirlik çalışması [A questionnaire for motivation toward science learning: A validity and reliability study]. Necati Bey Ĕ̈itim Fakültesi Elektronik Fen ve Matematik Ĕ̈itimi Dergisi, 2(1), 19-37.

Dembo, M. H. (2004). Motivation and learning strategies for college success:A self management approach $\left(2^{\text {nd }}\right.$ ed.). Mahwah: Lawrence Erlbaum Associates

Demir, R., Öztürk, N. \& Dökme, İ. (2012). İlköğretim 7. sınıf öğrencilerinin fen ve teknoloji dersine yönelik motivasyonlarının bazı değişkenler açısından incelenmesi [Investigation of 7th grade primary school students' motivation towards science and technology course in terms of some variables]. Mehmet Akif Ersoy Üniversitesi Ĕ̈itim Fakültesi Dergisi, 12(23), 1-21.

Dicke, A.-L., Lüdtke, O., Trautwein, U., Nagy, G., \& Nagy, N. (2012). Judging students' achievement goal orientations: are teacher ratings accurate?. Learning and Individual Differences, 22, 844-849.

Gömleksiz, M. N. \& Serhatlığlu, B. (2014). Öğretmen adaylarının akademik motivasyon düzeylerine ilişkin görüşleri [Prospective teachers' perceptions of academic motivation levels]. Türkiye Sosyal Araştırma Dergisi, 17 (3), 99-127. 
Green-Demers, I., Legault, L., Pelletier, D. \& Pelletier, L. G. (2008). Factorial invariance of the Academic Amotivation Inventory (AAI) across gender and grade in a sample of Canadian high school students. Educational and Psychological Measurement, 68(5), 862-880.

Green, J., Nelson, G., Martin, A. J. \& Marsh, H. (2006). The causal ordering of self-concept and academic motivation and its effect on academiz achievement. Internetional Education Journal, 7(4), 534-546.

İlter, İ. (2019). Akademik motivasyonsuzluk ölçeğinin Türk kültürüne uyarlanması [Adaptation of the Academic Amotivation Scale into Turkish Culture]. Ankara Üniversitesi Eğitim Bilimleri Fakültesi Dergisi, 52(1), 191-224.

Karaca, B. (2019). Fen bilimleri dersinde motivasyonsuz olan ögrencilerin motivasyonsuz olmalarına neden olan faktörlerin incelenmesi. (Master thesis). Kafkas University, Kars.

Kashef , M. M., Mazyari, M. \& Ameri, M. H. S., (2012). The relationship between support behaviours of physical education teachers and a motivation of students in physical education activities at schools. In The Asian Conference on Education, Osaka, Japan, Oct (pp. 24-28).

Khamis, V., Dukmak, S. \& Elhoweris, H., (2008). Factors affecting the motivation to learn among United Arab Emirates middle and high school students. Educational studies, 34(3), 191-200.

Linnenbrink, E. A. \& Pintrich, P. R. (2002). Motivation as an enabler for academic success. School Psychology Review, 31(3), 313-327.

Legault, L., Green-Demers, I. \& Pelletier, L. (2006). Why do high school students lack motivation in the classroom? Toward an understanding of academic amotivation and the role of social support. Journal of Educational Psychology, 98(3), 567-582.

McCombs, B. L. (1991). Motivation and lifelong learning. Educational psychologist, 26(2), 117-127.

Martin, A. J. \& Tracey, D. (2002). Motivating students to learn. Learning-Links Publication of Association for Children with Learning Disabilities. 3, 1-5.

Orsini, C., Binnie, V. I. \& Wilson, S. L. (2016). Determinants and outcomes of motivation in health professions education: a systematic review based on self-determination theory. Journal of educational evaluation for health professions, 13, 19.

Pelletier, L. G., Dion, S., Tuson, K. \& Green- Demers, I. (1999). Why do people fail to adopt environmental protective behaviors? Toward a taxonomy of environmental amotivation 1. Journal of Applied Social Psychology, 29(12), 2481-2504.

Pintrich, P. R. \& De Groot, E. V. (1990). Motivational and self-regulated learning components of classroom academic performance. Journal of Educational Psychology, 82(1), 33-40

Pintrich, P. R. \& Schunk, D. (1996). Motivation in education: Theory, research, and applications. Upper Saddle, NJ: Prentice-Hall, Inc.

Raffini, J. P. (1993). Winners without losers: Structures and strategies for increasing student motivation to learn. Boston: Allyn \& Bacon

Trumper, R. (1995). Students' motivational traits in science: A cross-age study. British Educational Research Journal, 21(4), 505-516.

Uzun, N. \& Keleş, Ö. (2010) . Fen öğrenemeye yönelik motivasyonun bazı demografik özelliklere göre değerlendirilmesi [Evaluation of the Motivation for Science Learning According to Some Demographic Characteristics]. Gazi Ĕ̈itim Fakültesi Dergisi, 30(2), 561-584.

Uzun, N. \& Keleş, Ö. (2012). İlköğretim öğrencilerinin fen öğrenmeye yönelik motivasyon düzeylerinin değerlendirilmesi [Evaluation of primary school students' motivation levels for science learning]. Mustafa Kemal Üniversitesi Sosyal Bilimler Enstitüsü Dergisi, 9(20), 313-327.

Uzgören-Gültan, C. (1999). İlköğretim okulları ikinci kademe ingilizce öğrencilerinin motivasyonu [Secondary school English students motivation]. (Master thesis). Marmara Üniversity, Sosyal Bilimler Enstitüsü, İstanbul.

Vallerand, R. J., Pelletier, L. G., Blais, M. R., Briere, N. M., Senecal, C. ve Vallieres, E. F. (1992). The Academic Motivation Scale: A measure of intrinsic, extrinsic, and amotivation in education. Educational and psychological measurement, 52(4), 1003-1017.

Vatansever-Bayraktar, H. (2015). Sinıf yönetiminde öğrenci motivasyonu ve motivasyonu etkileyen etmenler [Student motivation in classroom management and factors that affect motivation]. Electronic Turkish Studies, 10(3).

Vlachopoulos, S. P. \& Gigoudi, M. A. (2008). Why don't you exercise? Development of the amotivation toward exercise scale among older inactive individuals. Journal of aging and physical activity, 16(3), 316-341.

Yaman, S. \& Dede, Y. (2007). Öğrencilerin Fen ve Teknoloji ve Matematik dersine yönelik motivasyon düzeylerinin bazı değişkenler açısından incelenmesi [Examination of motivation level of students towards science and mathematics by some variables]. Kuram ve Uygulamada Eğitim Yönetimi, 52(52), 615-638. 
Yenice, N., Saydam, G. \& Telli, S. (2012). İlköğretim öğrencilerinin fen öğrenmeye yönelik motivasyonlarını etkileyen faktörlerin belirlenmesi. Ahi Evran Üniversitesi Kırşehir Eğitim Fakültesi Dergisi, 3(2), 231247.

Yerlikaya, İ. (2014). İlkokul ve ortaokul öğrencilerinin eğitime ilişkin motivasyonlarının çeşitli değişkenler açısından incelenmesi. Tarih Okulu Dergisi (TOD), 7, 773-795.

Yetim, E., Demir, Y. \& Erturan-İlker, G. ve (2016). Beden eğitimi derslerinde motivasyon, tutum ve motivasyonel stratejilerin tahmin edici etkisi. Spormetre Beden Eğitimi ve Spor Bilimleri Dergisi, 12(2), 139-146.

Zimmerman, B. J., Bandura, A., \& Martinez-Pons, M. (1992). Self-motivation for academic attainment: The role of self-efficacy beliefs and personal goal setting. American educational research journal, 29(3), 663-676.

\section{Author Information}

\section{Büșra Karaca}

Kafkas University, Dedekorkut Education Faculty

Science Education Department, Kars/TURKEY

Contact e-mail:bsrkskn25@gmail.com

\section{Solmaz Aydin}

Kafkas University, Dedekorkut Education Faculty

Science Education Department, Kars/TURKEY

ORCID iD: 0000-0003-0153-9545 
Appendix 1: Fen Bilimlerinde Motivasyonsuzluk Ölçeği (Turkish Version)

\section{Sevgili öğrenciler;}

Bu ölçek Fen Bilimleri dersini öğrenmeyi istememenizin sebeplerini belirlemek amacıyla hazırlanmıştır. Her bir maddeyi dikkatlice okuyarak size uygun gelen ifadeyi 1'den 5'e kadar puanlayınız. Katkılarınızdan dolayı teşekkür ederiz.

\section{Neden fen öğrenmek istemiyorsunuz?}

Çünkü ailemin maddi durumu fen dersindeki gerekli malzemeleri almaya

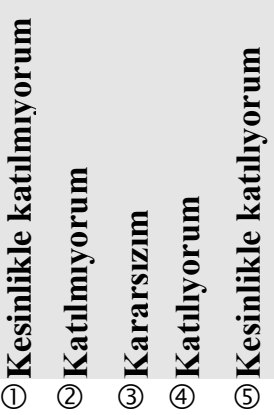
yetmiyor.

Çünkü evde fen ödevlerimi yapabilmek için internetim yok.

(1) (2) (3) (4) (5)

(1) (2) (3) (4) (5)

Çünkü ailemin eğitim durumu fen dersime yardım etmek için yeterli değil.

Çünkü okulumu sevmiyorum.

Çünkü arkadaşlarımla birlikte fen dersini çalışma imkanım olmuyor.

Çünkü öğretmenimiz fen dersini anlatırken bizimle hiç iletişim kurmuyor.

Çünkü fen dersinin gerekli olduğunu düşünmüyorum.

Çünkü fen dersini öğrenmek istemiyorum.

Çünkü fen dersini başarabileceğime inanmıyorum.

Çünkü fen dersini yapamayacağımdan korkuyorum.

Çünkü fen dersini sevmiyorum.

Çünkü fen dersini öğrenmek için bir hedefim yok.

Çünkü fen ödevlerimi yapabilmek için bilgisayarım(tablet-telefon vb.) yok.

Çünkü fen dersinde konuyu anlamadığım zaman öğretmenime soru sormaktan çekiniyorum.

Çünkü fen öğretmenimi sevmiyorum.

Çünkü öğretmenim fen dersini yapabileceğime inanmıyor.

Çünkü fen dersindeki konular bana zor geliyor.

Çünkü neden fen öğrenmem gerektiğini bilmiyorum.

Çünkü fen dersinde yeni bilgiler öğrenmiyorum.

Çünkü fen dersi benim için önemli bir ders değil.

Çünkü ailem fen dersini yapabileceğime inanmıyor.

Çünkü fen dersini öğrenmek işime yaramayacak.
(1) (2) (3) (4) (5)

(1) (2) (3) (4) (5)

(1) (2) (3) (4) (5)

(1) (2) (3) (4) (5)

(1) (2) (3) (4) (5)

(1) (2) (3) (4) (5)

(1) (2) (3) (4) (5)

(1) (2) (3) (4) (5)

(1) (2) (3) (4) (5)

(1) (2) (3) (4) (5)

(1) (2) (3) (4) (5)

(1) (2) (3) (4) (5)

(1) (2) (3) (4) (5)

(1) (2) (3) (4) (5)

(1) (2) (3) (4) 5

(1) (2) (3) (4) (5)

(1) (2) (3) (4) (5)

(1) (2) (3) (4) 5

(1) (2) (3) (4) (5) 
Appendix 2: Science Amotivation Scale

Dear students;

This scale has been prepared in order to determine the reasons for not wanting to learn Science course. Read each item carefully and score the expression that suits you from 1 to 5 . Thank you for your contribution.

Why don't you learn science?

Because my family's financial situation prevents me from buying materials necessary for science classes.

Because I do not have Internet at home to do my science homework.

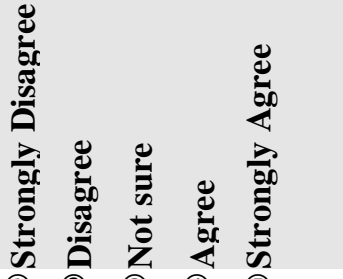

Because my parent's education level is not high enough to support me in science classes.

Because I do not like my school.

Because I do not have an opportunity to study for science classes with my friends.

Because our teacher does not interact with us when teaching science lessons.

Because I do not think science classes are necessary.

Because I do not want to learn science.

Because I do not believe that I can be successful in science.

(1) (2) (3) (4) (5)

(1) (2) (3) (4) (5)

(1) (2) (3) (4) (5)

(1) (2) (3) (4) (5)

(1) (2) (3) (4) (5)

(1) (2) (3) (4) (5)

(1) (2) (3) (4) (5)

(1) (2) (3) (4) (5)

Because I fear that I will not be successful in science classes.

(1) (2) (3) (4) (5)

Because I do not like science classes.

Because I do not have a goal to learn science.

Because I do not have a computer to do my science homework.

(1) (2) (3) (4) (5)

Because I abstain from asking questions to my teacher when I do not understand the

(1) (2) (3) (4) (5) subject in science classes.

Because I do not like my science teacher.

(1) (2) (3) (4) (5)

Because my teacher does not believe that I can be successful in science.

(1) (2) (3) (4) (5)

Because the subjects in science classes are difficult for me.

Because I do not know why I should learn science.

Because I do not learn new information in science classes.

Because science classes are not important for me.

Because my family does not believe that I can be successful in science.

(1) (2) (3) (4) (5)

Because learning science will not be useful. 